\title{
Correction to: Role of the DNA damage response in prostate cancer formation, progression and treatment
}

\author{
Wenhao Zhang ${ }^{1} \cdot$ Dik C. van Gent $\mathbb{D}^{1,2} \cdot$ Luca Incrocci $^{3} \cdot$ Wytske M. van Weerden ${ }^{4} \cdot$ Julie Nonnekens $\mathbb{D}^{1,5}$
}

Published online: 17 July 2019

(C) The Author(s), under exclusive licence to Springer Nature Limited 2019. This article is published with open access

\section{Correction to: Prostate Cancer and Prostatic Diseases https://doi.org/10.1038/s41391-019-0153-2 published online 12 June 2019}

This article was originally published under NPG's License to Publish, but has now been made available under a CC BY 4.0 license. The PDF and HTML versions of the paper have been modified accordingly.
Open Access This article is licensed under a Creative Commons Attribution 4.0 International License, which permits use, sharing, adaptation, distribution and reproduction in any medium or format, as long as you give appropriate credit to the original author(s) and the source, provide a link to the Creative Commons license, and indicate if changes were made. The images or other third party material in this article are included in the article's Creative Commons license, unless indicated otherwise in a credit line to the material. If material is not included in the article's Creative Commons license and your intended use is not permitted by statutory regulation or exceeds the permitted use, you will need to obtain permission directly from the copyright holder. To view a copy of this license, visit http://creativecommons. org/licenses/by/4.0/.
Julie Nonnekens

j.nonnekens@erasmusmc.nl

1 Department of Molecular Genetics, Erasmus MC, Rotterdam, The Netherlands

2 Oncode Institute, Erasmus MC, Rotterdam, The Netherlands

3 Department of Radiation Oncology, Erasmus MC Cancer Institute, Rotterdam, The Netherlands

4 Department of Experimental Urology, Erasmus MC, Rotterdam, The Netherlands

5 Department of Radiology and Nuclear Medicine, Erasmus MC, Rotterdam, The Netherlands 